\title{
Proposed Solution for Adaptation of the Block in TPP Bitola using Gas Turbine Combined Cycle
}

\author{
Blagoj Dimovski, Sevde Stavreva, Cvete Dimitrieska, Igor Andreevski \\ University St. Kliment Ohridski - Bitola, Faculty of Technical Sciences - Bitola, \\ Makedonska falanga 37, Bitola, R. N. Macedonia
}

\begin{abstract}
The subject of this paper is to present the possibility of adapting the existing conventional steam power station of TPP Bitola (Republic of North Macedonia) in a plant using gas turbine combined cycle (GTCC). The main emphasis is placed on the energy analysis of the conceptual plant where the required energy parameters of the individual components of the combined cycle are shown. The parameters of the superheated steam delivered by the boiler in the current operating mode are considered and they should be provided by heat recovery steam generator with the heat of the exhaust gases from the gas turbine to achieve a high degree of adjusted upgrade of the thermal power plant. Simplified schemes of the envisaged combined cycle consisting of two gas turbines and one steam turbine are given. $A$ comparative analysis of the efficiency and capacity of the existing and conceptual plant is performed.
\end{abstract}

Keywords - gas turbine, steam turbine, HRSG, combined cycle, energy analysis.

\section{Introduction}

Considering the depletion of the last coal reserves in the North Macedonia, as well as the current process

DOI: 10.18421/TEM111-19

https://doi.org/10.18421/TEM111-19

Corresponding author: Sevde Stavreva,

University St. Kliment Ohridski - Bitola, Faculty of Technical Sciences - Bitola, Bitola, R.N. Macedonia.

Email: sevde.stavreva@uklo.edu.mk

Received: 07 October 2021.

Revised: 14 January 2022.

Accepted: 19 January 2022.

Published: 28 February 2022.

(c) BY-NC-ND (C) 2022 Blagoj Dimovski et al; published by UIKTEN. This work is licensed under the Creative Commons Attribution-NonCommercial-NoDerivs 4.0 License.

The article is published with Open Access at www.temjournal.com of gasification with natural gas, the idea for a possible solution is imposed, i.e., adaptation of the block of TPP Bitola by applying a gas turbine combined cycle (GTCC).

Combined cycle power plants has higher efficiency than single gas turbine or steam turbine plants. Thus, the efficiency of steam turbine plants (including TPP Bitola) is $32 \%$ [1], while for combined cycle plants it reaches over $60 \%$ [2]. This is a major indicator of the rapid development and growing interest in the application of this type of plant in the world. In addition to this is the great availability of natural gas with positive economic and environmental parameters.

In the paper, energy analysis for distribution of the thermal energy in proposed conceptual solution in TPP Bitola is made.

\section{Analysis of Combined Cycle}

The existing conventional steam power plant operated in the block from TPP Bitola is given in the right part of Figure 1.

The proposed solution includes combined cycle in the block of TPP Bitola [3], which envisages to consist of two gas turbines, two heat recovery steam generators (HRSGs) and one steam turbine (K-210130) that already exists in TPP Bitola [1], [4]. A simplified schematic diagram of the combined cycle is shown in Figure 1.

The solution proposes that the exhaust gases from the two gas turbines are directed to the two HRSGs that use the heat to produce superheated steam. The superheated continue to the existing steam turbine without adding fuel, in the process of work, thus steam turbine cycle becomes a part of the combined cycle (CC).

The steam turbine in TPP Bitola (K-210-130) (Figure 1) has three cylinders: high, pressure (HP), intermediate pressure (IP) and low pressure (LP). The steam leaving the HP cylinder is returned to the HRSG on reheating to increase its parameters and then continues to the IP and LP cylinders to increase the cycle efficiency. 


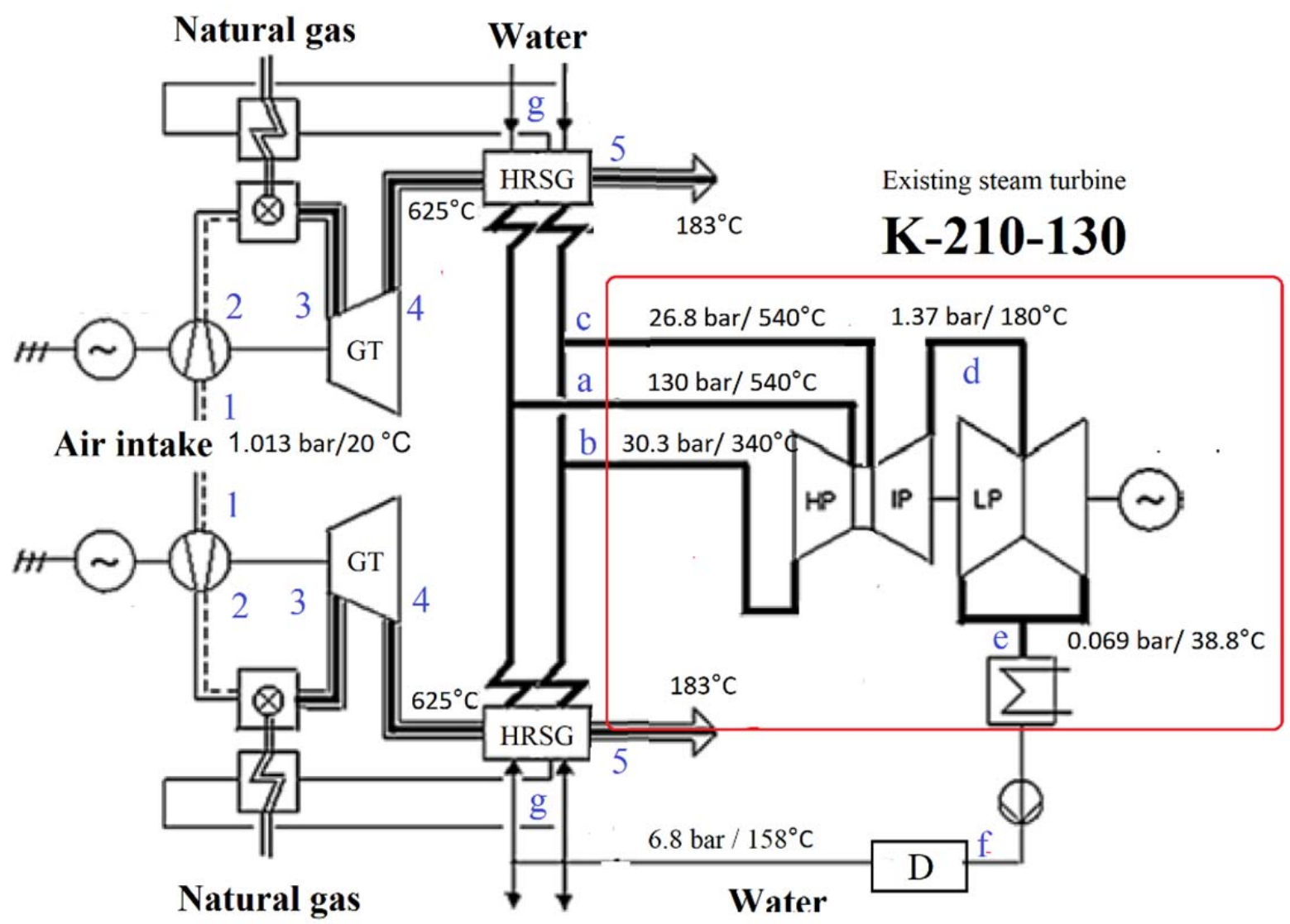

Figure 1. Conceptual solution for the combined cycle in TPP Bitola

This is how the cycles in the three blocks in TPP Bitola work, whereby HRSG is replacing the role of the steam generator (boiler). The purpose of this is to provide parameters for continuous operation and easy integration of the steam cycle from TPP Bitola to the combined cycle.

The heat transfer in the HRSG is complex, and it is a theme of many kinds of research [5] and optimization [6]. HRSG with dual pressure (high and intermediate) stages should be selected for the intended adaptation, which completely replaces the role of the existing steam boiler. The main parameter of HRSG is the required temperature difference $\left(\Delta t_{H R S G}\right)$ between the hot gases $\left(t_{\mathrm{p}}\right)$ and the steam saturation temperature $\left(t_{\text {saturation }}\right)$. If the hot gases temperature is not sufficient to reach the boiling point of the water, then additional burners are installed [7], which is not necessary in this case, due to the selected model of the combined cycle.

\section{Energy Analysis of the Separate Cycles and Segments of the Combined Cycle}

The energy analysis determines the energy distribution of each segment of the combined cycle to obtain the required parameters based on the first law of thermodynamics [8], [9].

\section{Steam Turbine Cycle}

The steam leaving both HRSGs enters the K-210130 condensing steam turbine. The input parameters of the steam in the existing steam turbine in TPP Bitola are mass flow $700 \mathrm{t} / \mathrm{h}$, pressure 130 bar, temperature $\left(t_{a}\right) 540{ }^{\circ} \mathrm{C}$ and specific enthalpy 3445 $\mathrm{kJ} / \mathrm{kg}$. The turbine has seven unregulated steam extraction points: two from the HP cylinder, four from the IP cylinder and one from the LP cylinder. The extracted steam accounts for $28 \%$ of the total steam and it is mainly used for LP and HP regenerative steam heaters [1], [4]. Table 1 shows the input and output parameters of the three cylinders and the condenser from the steam turbine, as well as its output power where the losses from extractions, pumps, and etc. are considered. These parameters are already known from the current operating mode of the steam turbine in TPP Bitola [1]. According to the parameters from Table 1, the total output power of the steam turbine is $W_{s t}=224 \mathrm{MW}$. 
Table 1. Parameters of the segments from a steam cycle in TPP Bitola

\begin{tabular}{|c|c|c|c|c|c|c|c|c|c|c|c|c|}
\hline \multirow{2}{*}{\multicolumn{2}{|c|}{ Parameter }} & \multicolumn{2}{|c|}{ HP } & \multicolumn{2}{|c|}{ IP } & \multicolumn{2}{|c|}{ LP } & \multicolumn{2}{|c|}{ Condenser } & \multicolumn{2}{|c|}{ Deaerator } & \\
\hline & & \multirow{2}{*}{$\begin{array}{c}\begin{array}{l}\text { Input } \\
\text { (a) }\end{array} \\
540 \\
\end{array}$} & \multirow{2}{*}{\begin{tabular}{|c|}
$\begin{array}{c}\text { Output } \\
\text { (b) }\end{array}$ \\
340 \\
\end{tabular}} & \multirow{2}{*}{\begin{tabular}{|c|}
$\begin{array}{c}\text { Input } \\
\text { (c) }\end{array}$ \\
540 \\
\end{tabular}} & \multirow{2}{*}{\begin{tabular}{|c|}
$\begin{array}{c}\text { Output } \\
\text { (d) }\end{array}$ \\
180 \\
\end{tabular}} & \multirow{2}{*}{$\begin{array}{c}\begin{array}{c}\text { Input } \\
\text { (d) }\end{array} \\
180 \\
\end{array}$} & \multirow{2}{*}{$\begin{array}{c}\begin{array}{l}\text { Output } \\
\text { (e) }\end{array} \\
38.8 \\
\end{array}$} & \multirow{2}{*}{$\begin{array}{c}\begin{array}{c}\text { Input } \\
\text { (e) }\end{array} \\
38.8 \\
\end{array}$} & \multirow{2}{*}{$\begin{array}{c}\begin{array}{c}\text { Output } \\
\text { (f) }\end{array} \\
38 \\
\end{array}$} & \multirow{2}{*}{$\begin{array}{c}\begin{array}{l}\text { Input } \\
\text { (f) }\end{array} \\
38 \\
\end{array}$} & \multirow{2}{*}{$\begin{array}{c}\begin{array}{c}\text { Output } \\
\text { (g) }\end{array} \\
158 \\
\end{array}$} & \\
\hline Temperature & {$\left[{ }^{\circ} \mathrm{C}\right]$} & & & & & & & & & & & \\
\hline Pressure & [bar] & 130 & 30.3 & 26.8 & 1.37 & 1.37 & 0.069 & 0.069 & 0.25 & 0.25 & 6.8 & \\
\hline Mass flow & {$[\mathrm{kg} / \mathrm{s}]$} & 194.4 & 169.4 & 166.7 & 137.5 & 137.5 & 132.2 & 132.2 & 139.7 & 139.7 & 139.7 & \\
\hline Enthalpy & {$[\mathrm{kJ} / \mathrm{kg}]$} & 3445 & 3094 & 3548 & 2834 & 2834 & 2458 & 2458 & 160 & 160 & 667 & \\
\hline Entropy & {$[\mathrm{kJ} / \mathrm{kg} \mathrm{K}]$} & 6.577 & 6.704 & 7.403 & 7.604 & 7.604 & 7.915 & 7.915 & 0.545 & 0.545 & 1.923 & \\
\hline Output power & [MW] & \multicolumn{2}{|c|}{68} & \multicolumn{2}{|c|}{98} & \multicolumn{2}{|c|}{58} & \multicolumn{2}{|c|}{1} & \multicolumn{2}{|c|}{1} & $22<4$ \\
\hline
\end{tabular}

\section{Heat Recovery Steam Generator (HRSG)}

The efficiency of the steam turbine is calculated by the expression:

$$
\eta_{s t}=\frac{W_{s t}}{Q_{s, i n}}
$$

Eq. (1) requires calculation of total thermal power $Q_{s, i n}$ of HRGSs for the steam cycle supply. The heat of the exhaust gases from the gas turbine is transferred to the supply water in the HRSG, which is obtained from the energy balance.

The change of the temperature of the exhaust gases and steam in the HRSG are given in Figure 2, where $t_{4}$ and $t_{5}$ are the temperature of the flue gases at the inlet or outlet of the HRSG, while $t_{g}$ is the temperature of the feed water from the deaerator, $t_{a}$ is the temperature of the steam at the outlet of the HRSG [1].

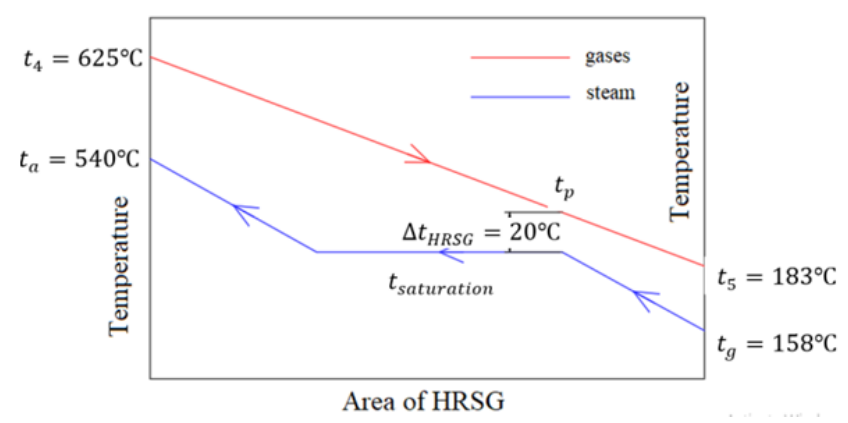

Figure 2. Exhaust gas and steam temperature change in HRSG

The temperature difference $\Delta t_{H R S G}$ between the temperature of the exhaust gases in the evaporator $\left(t_{\mathrm{p}}\right)$ and the saturation temperature $\left(t_{\text {saturation }}\right)$ is in the range of about $20^{\circ} \mathrm{C}$ (Figure 2). The produced steam that leaves both HRSGs enters the steam turbine with mass flow $2 \dot{m}_{s}=700 t / h \approx$ $194.4 \mathrm{~kg} / \mathrm{s}$, i.e., steam with mass flow $\dot{m}_{s}=$ $97.2 \mathrm{~kg} / \mathrm{s}$ is delivered from each HRSG. HRSG's thermal power $\left(Q_{H R S G}\right)$, and total thermal power of the two HRSGs $\left(Q_{s, i n}\right)$ are determined from the heat balance.
Based on the required parameters to be reached in the combined cycle, gas turbine is selected where the exhaust temperature of the hot gases is $t_{4}=625^{\circ} \mathrm{C}$, which is an upper limit of the series of models of gas turbines [1], [10]. Therefore, the mass flow of gases that maintains the balance is $m_{g}=550.44 \mathrm{~kg} / \mathrm{s}$. Table 2 shows the HRSG parameters that form eq. (2) and correspond to the entire combined cycle.

Table 2. HRSG parameters

\begin{tabular}{|c|c|c|c|c|}
\hline \multirow{2}{*}{ Parameter } & \multicolumn{2}{|c|}{ Gases } & \multicolumn{2}{c|}{ Steam } \\
\cline { 2 - 5 } & Input (4) & Output (5) & Input (g) & Output (a) \\
\hline $\begin{array}{c}\text { Temperature } \\
{\left[{ }^{\circ} \mathrm{C}\right]}\end{array}$ & 625 & 183 & 158 & 540 \\
\hline $\begin{array}{c}\text { Pressure } \\
{[\mathrm{bar}]}\end{array}$ & 1.013 & 1.013 & 6.8 & 130 \\
\hline $\begin{array}{c}\text { Mass flow } \\
{[\mathrm{kg} / \mathrm{s}]}\end{array}$ & $\mathrm{m}_{\mathrm{g}}=550.44$ & \multicolumn{2}{|c|}{$\mathrm{m}_{\mathrm{s}}=194.4$} \\
\hline $\begin{array}{c}\text { Enthalpy } \\
{[\mathrm{kJ} / \mathrm{kg}]}\end{array}$ & 930.8 & 506.1 & 666.9 & 3445 \\
\hline $\begin{array}{c}\text { Entropy } \\
{[\mathrm{kJ} / \mathrm{kgK}]}\end{array}$ & 6.845 & 6.125 & 1.923 & 6.577 \\
\hline $\begin{array}{c}\text { QHRSG } \\
{[\mathrm{MW}]}\end{array}$ & \multicolumn{3}{|c|}{270} \\
\hline $\begin{array}{c}\text { Qs,in } \\
{[\mathrm{MW}]}\end{array}$ & \multicolumn{3}{|c|}{540} \\
\hline
\end{tabular}

The efficiency of the steam turbine $\left(\eta_{s t}\right)$, calculated according to equation (1) is 0.415 .

\section{Gas Turbine Cycle}

The natural gas used in the cycle has a low heating $H_{d}=47.866 \mathrm{MJ} / \mathrm{kg}$ [7]. If it considers that the ratio of mass flow of air and natural gas in the combustion mixture is 44.86 [11], then the mass flows of fuel $\left(m_{f}\right)$ and air $\left(m_{a}\right)$ are $12 \mathrm{~kg} / \mathrm{s}$ and $538.44 \mathrm{~kg} / \mathrm{s}$ respectively, Table 3 . There is a dependence between the inlet air and fuel temperature and the outlet performance and efficiency of the gas turbine [12], [13]. 
Table 3. Input and output parameters of the gas turbine cycle

\begin{tabular}{|c|c|c|c|c|c|c|c|c|c|}
\hline \multirow{3}{*}{\multicolumn{2}{|c|}{ Parameter }} & \multicolumn{3}{|c|}{ Compressor } & \multicolumn{2}{|c|}{ Combustion chamber } & \multicolumn{3}{|c|}{ Gas turbine } \\
\hline & & \multicolumn{2}{|c|}{1} & \multicolumn{2}{|c|}{2} & \multicolumn{2}{|c|}{3} & \multirow{2}{*}{\multicolumn{2}{|c|}{$\begin{array}{c}4 \\
\text { output }\end{array}$}} \\
\hline & & \multicolumn{2}{|c|}{ input } & output & input & output & input & & \\
\hline Temperature & {$\left[{ }^{\circ} \mathrm{C}\right]$} & $\mathrm{t}_{1}$ (air) & 20 & $t_{2}$ (air) & 478 & $t_{3}$ & 1297 & $t_{4}$ & 625 \\
\hline Pressure & [bar] & \multicolumn{2}{|c|}{1.013} & \multicolumn{2}{|c|}{17.73} & \multicolumn{2}{|c|}{17.73} & \multicolumn{2}{|c|}{1.013} \\
\hline Mass flow & {$[\mathrm{kg} / \mathrm{s}]$} & \multicolumn{2}{|c|}{$\mathrm{m}_{a}$ (air) } & \multicolumn{2}{|c|}{538.44} & \multicolumn{2}{|c|}{$\mathrm{m}_{\mathrm{g}}$ (gases) } & \multicolumn{2}{|c|}{550.44} \\
\hline Enthalpy & {$[\mathrm{kJ} / \mathrm{kg}]$} & $i_{1}$ & 294 & $\mathrm{i}_{2}$ & 759.1 & $\mathrm{i}_{3}$ & 1724 & $\mathrm{i}_{4}$ & 930.8 \\
\hline Entropy & {$[\mathrm{kJ} / \mathrm{kgK}]$} & $\mathrm{S}_{1}$ & 5.77 & $\mathrm{~S}_{2}$ & 5.827 & $\mathrm{~S}_{3}$ & 6.678 & $\mathrm{~S}_{4}$ & 6.845 \\
\hline
\end{tabular}

The calculations are performed for the ambient air temperature of $t_{1}=20^{\circ} \mathrm{C}$. The isentropic efficiency for the compressor is $\eta_{a(c)}=0.85$, for the gas turbine is $\eta_{a(t)}=0.9$. The mechanical efficiency for the compressor is $\eta_{m(c)}=0.995$ and for the gas turbine $\eta_{m(t)}=0.998[11]$.

Compressor work $\left(W_{c}\right)$ and gas turbine output $\left(W_{t}\right)$ are calculated using the parameters shown in Table 3, in which the difference $\left(W_{t}-W_{c}\right)$ determines the gas turbine cycle output $\left(W_{G T}\right)$. The cycle efficiency $\left(\eta_{G T}\right)$ is calculated based on the low heat value of the fuel $\left(H_{d}\right)$. Table 4 provides an overview of the calculated gas turbine cycle parameters.

Table 4. Gas cycle parameters

\begin{tabular}{|c|c|c|c|}
\hline \multicolumn{2}{|c|}{ Fuel } & \multicolumn{2}{|c|}{ Compressor } \\
\hline $\mathrm{H}_{\mathrm{g}}[\mathrm{kJ} / \mathrm{kg}]$ & 55.53 & $\eta_{a}[-]$ & 0.85 \\
\hline $\mathrm{H}_{\mathrm{d}}[\mathrm{kJ} / \mathrm{kg}]$ & 47.866 & $\eta_{\mathrm{m}}[-]$ & 0.995 \\
\hline $\mathrm{m}_{\mathrm{f}}[\mathrm{kg} / \mathrm{s}]$ & 12 & $\mathrm{~W}_{\mathrm{C}}[\mathrm{MW}]$ & 251.47 \\
\hline $\mathrm{Q}_{\mathrm{f}}[\mathrm{MW}]$ & 574.39 & \multicolumn{2}{|c|}{ Combustion chamber } \\
\hline \multicolumn{2}{|c|}{ Air } & $\eta_{a}[-]$ & 0.99 \\
\hline $\mathrm{t}\left[{ }^{\circ} \mathrm{C}\right]$ & 20 & $\mathrm{Q}_{\text {in }}[\mathrm{MW}]$ & 519.54 \\
\hline $\mathrm{m}_{a}[\mathrm{~kg} / \mathrm{s}]$ & 538.44 & \multicolumn{2}{|c|}{ Gas turbine } \\
\hline $\mathrm{p}$ [bar] & 1.013 & $\eta_{a}[-]$ & 0.9 \\
\hline \multicolumn{2}{|c|}{ Gases } & $\eta_{\mathrm{m}}[-]$ & 0.998 \\
\hline $\mathrm{c}_{\mathrm{p}}[\mathrm{kJ} / \mathrm{kgK}]$ & 1.11 & $\mathrm{~W}_{\mathrm{t}}[\mathrm{MW}]$ & 435.74 \\
\hline $\mathrm{m}_{\mathrm{g}}[\mathrm{kg} / \mathrm{s}]$ & 550.44 & \multicolumn{2}{|c|}{ TOTAL CYCLE } \\
\hline & & $\mathrm{W}_{\mathrm{GT}}[\mathrm{MW}]$ & 184.27 \\
\hline & & $\eta_{\mathrm{GT}}[-]$ & 0.321 \\
\hline
\end{tabular}

The gas cycle provides a net power of $368.54 \mathrm{MW}$ $(2 \cdot 184.27 \mathrm{MW})$ and the outlet temperature of the gases from each gas turbine is $625^{\circ} \mathrm{C}$.

The heat used by two gas turbines from the fuel is:

$$
Q_{f, \text { total }}=2 \cdot Q_{f}
$$

The total output power and efficiency of the combined cycle is:

$$
\begin{aligned}
& W_{\text {total }}=2 \cdot W_{G T}+W_{s t} \\
& \eta_{\text {total }}=\frac{W_{\text {total }}}{Q_{f, \text { total }}}
\end{aligned}
$$

The calculated values of the heat dissipated from the condenser $\left(Q_{\text {cond. }}\right)$ and the heat losses in the environment with the exhaust gases $\left(Q_{\text {env }}\right)$ leaving the HRSG through the chimney are shown in Figure 3.

The other losses that complete the energy balance of the system are:

$$
Q_{\text {loses }}=Q_{f, \text { total }}-2 W_{G T}-W_{S T}-Q_{\text {cond. }}-Q_{\text {env. }}
$$

The energy distribution throughout the system is shown in Figure 3.

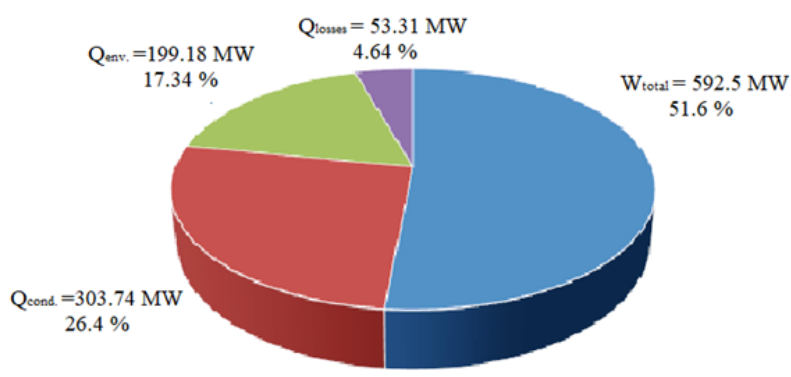

Figure 3. Energy distribution throughout the combined cycle

The ratio between the output power of the block using GTCC with the current power of the three blocks in TPP Bitola is:

$$
\Delta=\frac{W_{S T}}{W_{\text {total }}}
$$

In case of possible adaptation of the three blocks in TPP Bitola using GTCC, output power is:

$$
W_{T P P}=3 \cdot W_{\text {total }}
$$




\section{Conclusion}

A conceptual solution for adaptation of the block in TPP Bitola for conventional to combined cycle is presented in this paper, where the function of the boiler is replaced by two HRSGs which use the heat of the exhausted gases from two gas turbines. Thus, the block produces output power of $592.54 \mathrm{MW}$, which is $88.2 \%$ of the current power of the three units in TPP Bitola that operate on the conventional principle. Implementation of this idea is a capital investment that includes increased efficiency up to $51.6 \%$. The use of the natural gas as a primary fuel solves the problem of the limited depletion of reserves with quality coal (lignite) and has a negligible negative impact on the environment.

\section{References}

[1]. Dimovski, V. (2013). Modernizacija na termoenergetski postrojki so osvrt na Termoelektrana Bitola. Magisterski trud.Tehnicki fakultet, Bitola, 428.

[2]. Blumberg, T., Assar, M., Morosuk, T., \& Tsatsaronis, G. (2017). Comparative exergoeconomic evaluation of the latest generation of combined-cycle power plants. Energy Conversion and Management, 153, 616-626.

[3]. Oh, H. S., Lee, Y., \& Kwak, H. Y. (2017). Diagnosis of combined cycle power plant based on thermoeconomic analysis: A computer simulation study. Entropy, 19(12), 643.

[4]. Pecakov,S. (1996).Osnovi za eksploatacija na energetski blokovi - JP Elektrostopnastvo na Makedonija. REK Bitola, 133-214.

[5]. Li, J., Wang, K., \& Cheng, L. (2017). Experiment and optimization of a new kind once-through heat recovery steam generator (HRSG) based on analysis of exergy and economy. Applied thermal engineering, 120, 402-415.

[6]. Naserabad, S. N., Mehrpanahi, A., \& Ahmadi, G. (2018). Multi-objective optimization of HRSG configurations on the steam power plant repowering specifications. Energy, 159, 277-293.

[7]. Ahmadi, P., \& Dincer, I. (2011). Thermodynamic analysis and thermoeconomic optimization of a dual pressure combined cycle power plant with a supplementary firing unit. Energy Conversion and Management, 52(5), 2296-2308.

[8]. Qu, X., Yang, X., \& Wang, J. (2017). A study on different thermodynamic cycle schemes coupled with a high temperature gas-cooled reactor. Annals of Nuclear Energy, 106, 185-194.

[9]. Moran, M. J., Shapiro, H. N., Boettner, D. D., \& Bailey, M. B. (2010). Fundamentals of engineering thermodynamics. John Wiley \& Sons.

[10]. Brooks, F. J. (2000). GE gas turbine performance characteristics. GE Power Systems, Schenectady, NY.

[11]. Darwish, M., Abdulrahim, H., Mabrouk, A., \& Hassan, A. (2015). Cogeneration power-desalting plants using gas turbine combined cycle. Desalination updates.

[12]. Marin, G., Mendeleev, D., Osipov, B., \& Akhmetshin, A. (2020). Study of the effect of fuel temperature on gas turbine performance. In E3S Web of Conferences (Vol. 178, p. 01033). EDP Sciences.

[13]. Ibrahim, T. K., Rahman, M. M., \& Abdalla, A. N. (2011). Gas turbine configuration for improving the performance of combined cycle power plant. Procedia Engineering, 15, 4216-4223. 